\title{
UPAYA MENINGKATKAN PRESTASI BELAJAR PKN MELALUI METODE PEMBELAJARAN KOOPERATIF MODEL STAD
}

\author{
Suswani \\ SDN 3 Pangkalpinang \\ suswanipkp@gmail.com
}

\begin{abstract}
Abstrak
Penelitian dilaksanakan dalam tiga siklus kegiatan berdasarkan materi pembelajaran. Hasil penelitian menunjukkan bahwa penerapan metode Pembelajaran Kooperatif Model STAD dapat meningkatkan keaktifan peserta didik dalam proses pembelajaran yang berdampak pada peningkatan hasil belajar yang dicapai mereka. Hal ini terlihat peningkatan rata-rata nilai dan persentase ketuntasan yang diperoleh peserta didik, dimana rata-rata nilai pada siklus I 6,79, siklus II 7,29, dan siklus III 7,97. Sedangkan untuk persentase ketuntasan berturut-turut pada siklus I $68,42 \%$, siklus II $81,58 \%$, dan siklus III 94,74\%. Walaupun belum mencapai ketuntasan $100 \%$, tetapi terjadi peningkatan persentase ketuntasan yang cukup signifikan. Kesimpulan dari penelitian ini, yakni penerapan metode Pembelajaran Kooperatif Model STAD dalam proses pembelajaran PKn dapat meningkatkan hasil belajar peserta didik yang terindikasi dari nilai tes yang diperoleh.
\end{abstract}

Kata Kunci: Hasil Belajar; Metode Pembelajaran; STAD.

\begin{abstract}
The study was conducted in three activity cycles based on learning material. The results showed that the application of the STAD Model Cooperative Learning method can increase the activeness of students in the learning process that has an impact on improving the learning outcomes achieved by them. This can be seen in an increase in the average value and percentage of completeness obtained by students where the average value in cycle I was 6,79, cycle II 7,29, and cycle III 7,97. As for the percentage of completeness in succession in the first cycle 68,42\%, the second cycle 81,58\%, and the third cycle 94,74\%. Although it has not reached $100 \%$ completeness there is a significant increase in the percentage of completeness. The conclusion of this study is the application of the STAD Model Cooperative Learning method in the Civics Education learning process can improve student learning outcomes as indicated by the test scores obtained.
\end{abstract}

Keywords: Learning Outcomes; Learning Method; STAD. 


\section{Edutainment : Jurnal Ilmu Pendidikan dan Kependidikan}

Volume 7 Nomor 2 Edisi Juli-Desember 2019

\section{PENDAHULUAN}

Guru memiliki peranan yang sangat penting dalam menentukan kuantitas dan kualitas pengajaran yang dilaksanakan. Oleh sebab itu, guru harus memikirkan dan membuat perencanaan secara seksama dalam meningkatkan kesempatan belajar bagi siswa dan memperbaiki kualitas mengajar. Hal ini menuntut perubahanperubahan dalam mengorganisasikan kelas, penggunaan metode mengajar, strategi belajar mengajar, maupun sikap dan karakteristik guru dalam mengelola proses belajar mengajar. Guru berperan sebagai pengelola proses belajar-mengajar, bertindak sebagai fasilitator yang berusaha menciptakan kondisi belajar mengajar yang efektif, sehingga memungkinkan proses belajar mengajar, mengembangkan bahan pelajaran dengan baik, dan meningkatkan kemampuan siswa untuk menyimak pelajaran dan menguasai tujuan-tujuan pendidikan yang harus mereka capai. Untuk memenuhi hal tersebut di atas, guru dituntut mampu mengelola proses belajar mengajar yang memberikan rangsangan kepada siswa, sehingga ia mau belajar, karena siswa merupakan subjek utama dalam belajar.

Pada kenyataannya di sekolah seringkali guru yang aktif, tetapi siswa tidak diberi kesempatan untuk aktif. Kegiatan belajar bersama dapat membantu memacu belajar aktif. Kegiatan belajar dan mengajar di kelas memang dapat menstimulasi belajar aktif. Kemampuan untuk mengajar melalui kegiatan kerjasama kelompok kecil akan memungkinkan untuk menggalakkan kegiatan belajar aktif dengan cara khusus.

Pembelajaran PKn tidak lagi mengutamakan pada penyerapan melalui pencapaian informasi, tetapi lebih mengutamakan pada pengembangan kemampuan dan pemrosesan informasi. Untuk itu aktivitas peserta didik perlu ditingkatkan melalui latihan-latihan atau tugas dengan bekerja dalam kelompok kecil dan menjelaskan ide-ide kepada orang lain (Hartoyo, 2000:24).

Pembelajaran kooperatif lebih menekankan interaksi antar siswa. Dari sini siswa akan melakukan komunikasi aktif dengan sesama temannya. Dengan komunikasi tersebut diharapkan siswa dapat menguasai materi pelajaran dengan mudah, karena siswa lebih mudah memahami penjelasan dari kawannya dibanding penjelasan dari guru, karena taraf pengetahuan serta pemikiran mereka lebih sejalan dan sepadan (Sulaiman dalam Wahyuni 2001:2).

Berdasarkan paparan tersebut, maka peneliti ingin mencoba melakukan penelitian dengan judul "Upaya Meningkatkan Prestasi Belajar PKn Melalui Metode Pembelajaran Kooperatif Model STAD (Student Teams Achievement 


\section{Edutainment : Jurnal Ilmu Pendidikan dan Kependidikan}

Volume 7 Nomor 2 Edisi Juli-Desember 2019

Division) pada Siswa Kelas VB SD Negeri

3 Pangkalpinang". Berdasarkan latar belakang di atas dapat diidentifikasi beberapa permasalahan yang dapat diangkat, yakni apakah terdapat pengaruh terhadap prestasi belajar dengan menggunakan metode STAD? dan apakah pembelajaran dengan menggunakan metode STAD dapat meningkatkan prestasi belajar?

Bertitik tolak dari identifikasi masalah di atas, maka penulis merumuskan permasalahannya, yakni bagaimanakah peningkatan prestasi belajar PKn dengan diterapkannya metode pembelajaran kooperatif model STAD pada siswa kelas VB semester II SD Negeri 3 Pangkalpinang tahun pelajaran 2017/2018? dan bagaimanakah pengaruh metode pembelajaran kooperatif model STAD terhadap prestasi belajar PKn pada siswa kelas VB SD Negeri 3 Pangkalpinang?

\section{METODE PENELITIAN}

Tempat penelitian dilakukan di SD Negeri 3 Pangkalpinang jalan Tampuk Pinang Pura Kel. Kacang Pedang Kec. Gerunggang, dan waktu penelitian dilakukan pada semester 1 tahun pelajaran 2017/2018. Penelitian dilakukan pada bulan Agustus sampai dengan Oktober 2017. Subjek penelitian ini siswa-siswi kelas VB semester 1 SD Negeri 3 Pangkalpinang Tahun Pelajaran 2017/2018, pada Standar Kompetensi:
Memahami kebebasan berorganisasi, dan Kompetensi Dasar: Mendeskripsikan pengertian organisasi.

Alat pengumpul data dalam penelitian ini tes buatan guru yang fungsinya, yakni untuk menentukan seberapa baik siswa telah menguasai bahan pelajaran yang telah diberikan dalam waktu tertentu; untuk menentukan apakah suatu tujuan telah tercapai; dan untuk memperoleh suatu nilai (Arikunto, 2002). Sedangkan tujuan dari tes untuk mengetahui ketuntasan belajar siswa secara individual maupun secara klasikal. Di samping itu, untuk mengetahui letak kesalahankesalahan yang dilakukan siswa, sehingga dapat dilihat dimana kelemahannya, khususnya pada bagian mana TPK yang belum tercapai. Untuk memperkuat data yang dikumpulkan, maka juga digunakan metode observasi (pengamatan) yang dilakukan oleh teman sejawat untuk mengetahui dan merekam aktivitas guru dan siswa dalam proses belajar mengajar.

Untuk menganalisis tingkat keberhasilan atau persentase keberhasilan siswa setelah proses belajar mengajar setiap putarannya dilakukan dengan cara memberikan evaluasi berupa soal tes tertulis pada setiap akhir putaran.

Analisis ini dihitung dengan menggunakan statistik sederhana, yakni untuk menilai ulangan atau tes formatif. Peneliti melakukan penjumlahan nilai 
Edutainment : Jurnal Ilmu Pendidikan dan Kependidikan

Volume 7 Nomor 2 Edisi Juli-Desember 2019

yang diperoleh siswa, selanjutnya dibagi dengan jumlah siswa yang ada di kelas tersebut, sehingga diperoleh rata-rata tes formatif dapat dirumuskan:

$\overline{\mathrm{X}}=\frac{\Sigma x}{\Sigma \mathrm{N}}$, Dengan:

$\overline{\mathrm{X}} \quad=$ Nilai rata-rata

$\sum \mathrm{X}=$ Jumlah semua nilai siswa

$\sum \mathrm{N}=$ Jumlah siswa

Sementara itu, untuk ketuntasan belajar, ada dua kategori ketuntasan belajar, yakni secara perorangan dan secara klasikal. Berdasarkan petunjuk pelaksanaan belajar mengajar kurikulum 1994 (Depdikbud, 1994) bahwa seorang siswa telah tuntas belajar bila telah mencapai skor $65 \%$ atau nilai 65 , dan kelas disebut tuntas belajar baik di kelas tersebut terdapat $85 \%$ yang telah mencapai daya serap lebih dari atau sama dengan $65 \%$. Untuk menghitung persentase ketuntasan belajar digunakan rumus sebagai berikut:

$\mathrm{P}=\frac{\Sigma \text { Siswa.yang.tuntas.belajar }}{\Sigma \text { Siswa }} \times 100 \%$

Kemudian, untuk lembar observasi, yakni lembar observasi pengelola metode pembelajaran kooperatif model STAD. Untuk menghitung lembar observasi pengelolaan metode pembelajaran kooperatif model STAD digunakan rumus sebagai berikut:

$\overline{\mathrm{X}}=\frac{P 1+P 2}{2}$
Dimana: $\mathrm{P} 1$ = Pengamat 1

$$
\text { P2 = Pengamat } 2
$$

Lembar observasi aktivitas guru dan siswa. Untuk menghitung lembar observasi aktivitas guru dan siswa digunakan rumus sebagai berikut:

$\%=\frac{\bar{x}}{\Sigma x} \times 100 \%$ dengan

$\mathrm{X}=\frac{\text { Jumah.hasil.pengama } \tan }{\text { Jumlah.pengama } \tan }$

$=\frac{P 1+P 2}{2}$

Dimana $\%=$ Persentase pengamatan

$\overline{\mathrm{X}} \quad=$ Rata-rata

$\sum \overline{\mathrm{x}} \quad=$ Jumlah rata-rata

P1 = Pengamat 1

$\mathrm{P} 2=$ Pengamat 2

Target pencapaian ketuntasan belajar siswa sebesar 94,74\% (termasuk kategori tuntas).

\section{HASIL DAN PEMBAHASAN}

Data penelitian diperoleh dari data observasi berupa pengamatan pengelolaan metode pembelajaran kooperatif model STAD dan pengamatan aktivitas guru dan siswa pada setiap siklus.

Data lembar observasi diambil dari dua pengamatan, yakni data pengamatan pengelolaan metode pembelajaran kooperatif model STAD yang digunakan untuk mengetahui pengaruh penerapan metode pembelajaran kooperatif model STAD dalam meningkatkan prestasi 


\section{Edutainment : Jurnal Ilmu Pendidikan dan Kependidikan}

Volume 7 Nomor 2 Edisi Juli-Desember 2019

belajar siswa dan data pengamatan aktivitas guru dan siswa.

Data tes formatif untuk mengetahui peningkatan prestasi belajar siswa setelah diterapkannya metode pembelajaran kooperatif model STAD.

\section{Siklus I}

Pada tahap ini peneliti mempersiapkan perangkat pembelajaran yang terdiri dari rencana pelajaran 1 , soal tes formatif I dan alat-alat pengajaran yang mendukung. Selain itu, dipersiapkan juga lembar observasi pengolahan metode pembelajaran kooperatif model STAD, dan lembar observasi aktivitas guru dan siswa.

Pelaksanaan kegiatan belajar mengajar untuk siklus I dilaksanakan pada tanggal 2 Agustus 2017 di Kelas VB dengan jumlah siswa 38 siswa. Pelaksanaan metode pembelajaran kooperatif model STAD melalui tahapan sebagai berikut: (1) Pelaksanaan pembelajaran, (2) Diskusi kelompok, (3) Tes, (4) Penghargaan kelompok, (5) Menentukan nilai individual dan kelompok. Pada akhir proses belajar mengajar siswa diberi tes formatif I dengan tujuan untuk mengetahui tingkat keberhasilan siswa dalam proses belajar mengajar yang telah dilakukan.

Hasil observasi tampak bahwa aktivitas guru yang paling dominan pada siklus I yaitu membimbing dan mengamati siswa dalam menemukan konsep, yakni 21,7\%. Aktivitas lain yang persentasinya cukup besar, yakni memberi umpan balik/ evaluasi, tanya jawab dan menjelaskan materi yang sulit yaitu masing-masing sebesar 13,3\%. Sedangkan aktivitas siswa yang paling dominan, yakni mengerjakan/ memperhatikan penjelasan guru yaitu 22,5\%. Aktivitas lain yang persentasinya cukup besar, yakni bekerja dengan sesama anggota kelompok, diskusi antar siswa/ antara siswa dengan guru, dan membaca buku yaitu masing-masing 18,7\%, 14,4\%, dan $11,5 \%$.

Hasil belajar pada siklus I diperoleh nilai rata-rata prestasi belajar siswa yaitu 6,79 dan ketuntasan belajar mencapai $68,42 \%$ atau ada 26 siswa dari 38 siswa sudah tuntas belajar. Hasil ini menunjukkan bahawa pada siklus I secara klasikal siswa belum tuntas belajar, karena siswa yang memperoleh nilai $\geq 65$ hanya sebesar 68,42\% lebih kecil dari persentase ketuntasan yang dikehendaki yaitu sebesar 85\%. Hal ini disebabkan karena siswa masih merasa baru dan belum mengerti apa yang dimaksudkan dan digunakan guru dengan menerapkan metode pembelajaran kooperatif model STAD. Pelaksanaan kegiatan belajar mengajar pada siklus I ini masih terdapat kekurangan, sehingga perlu adanya revisi untuk dilakukan pada siklus berikutnya.

\section{Siklus II}

Pada tahap ini peneliti mempersiapkan perangkat pembelajaran yang terdiri dari 


\section{Edutainment : Jurnal Ilmu Pendidikan dan Kependidikan}

Volume 7 Nomor 2 Edisi Juli-Desember 2019

rencana pembelajaran 2 , soal tes formatif

2, dan alat-alat pengajaran yang mendukung. Selain itu, dipersiapkan juga lembar observasi pengelolaan metode pembelajaran kooperatif model STAD dan lembar observasi guru dan siswa.

Pelaksanaan kegiatan belajar mengajar untuk siklus II dilaksanakan pada tanggal 23 Agustus 2017 di Kelas VB dengan jumlah siswa 38 siswa. Pelaksanaan metode pembelajaran kooperatif model STAD melalui tahapan sebagai berikut: (1) Pelaksanaan pembelajaran, (2) Diskusi klompok, (3) Tes, (4) Penghargaan kelompok, (5) Menentukan nilai individual dan kelompok. Dalam hal ini, peneliti bertindak sebagai pengajar, sedangkan yang bertindak sebagai pengamat, yakni seorang guru PKn dan Wali Kelas VB. Adapun proses belajar mengajar mengacu pada rencana pelajaran dengan memperhatikan revisi pada siklus I, sehingga kesalahan atau kekurangan pada siklus I tidak terulang lagi pada siklus II. Pengamatan (observasi) dilaksanakan bersamaan dengan pelaksanaan belajar mengajar.

Pada akhir proses belajar mengajar, siswa diberi tes formatif II dengan tujuan untuk mengetahui tingkat keberhasilan siswa dalam proses belajar mengajar yang telah dilakukan. Instrumen yang digunakan yaitu tes formatif II. Adapun data hasil penelitian pada siklus II terlihat aspek- aspek yang diamati pada kegiatan belajar mengajar yang dilaksanakan oleh guru dengan menerapkan metode pembelajaran kooperatif model STAD mendapatkan penilaian yang cukup baik dari pengamat. Maksudnya dari seluruh penilaian tidak terdapat nilai kurang. Namun demikian, penilaian tersebut belum merupakan hasil yang optimal, untuk itu, ada beberapa aspek yang perlu mendapatkan perhatian untuk penyempurnaan penerapan pembelajaran selanjutnya. Aspek-aspek tersebut, yakni memotivasi siswa, membimbing siswa merumuskan kesimpulan/menemukan konsep, dan pengelolaan waktu.

Berdasarkan observasi tampak bahwa aktivitas guru yang paling dominan pada siklus II, yakni membimbing dan mengamati siswa dalam menentukan konsep yaitu 25\%. Jika dibandingkan dengan siklus I, aktivitas ini mengalami peningkatan. Aktivitas guru yang mengalami penurunan, yakni memberi umpan balik/evaluasi/tanya jawab $(16,6 \%)$, menjelaskan materi yang sulit $(11,7)$, meminta siswa mendiskusikan dan menyajikan hasil kegiatan $(8,2 \%)$, dan membimbing siswa merangkum pelajaran $(6,7 \%)$.

Hasil belajar pada silus II diperoleh nilai rata-rata prestasi belajar siswa yaitu 7,29 dan ketuntasan belajar mencapai $81,58 \%$, artinya 31 dari 38 siswa sudah 


\section{Edutainment : Jurnal Ilmu Pendidikan dan Kependidikan}

Volume 7 Nomor 2 Edisi Juli-Desember 2019

tuntas belajar. Hasil ini menunjukkan bahwa pada siklus II ini ketuntasan belajar secara klasikal telah mengalami peningkatan sedikit lebih baik dari siklus I. Adanya peningkatan hasil belajar siswa ini, karena setelah guru menginformasikan bahwa setiap akhir pelajaran akan selalu diadakan tes, sehingga pada pertemuan berikutnya siswa lebih termotivasi untuk belajar. Selain itu, siswa juga sudah mulai mengerti apa yang dimaksudkan dan diinginkan guru dengan menerapkan metode pembelajarn kooperatif model STAD.

Pelaksanan kegiatan belajar pada Siklus II ini masih terdapat kekurangankekurangan. Maka perlu adanya revisi untuk dilaksanakan pada siklus II antara lain: Guru dalam memotivasi siswa hendaknya dapat membuat siswa lebih termotivasi selama proses belajar mengajar berlangsung, Guru harus lebih dekat dengan siswa, sehingga tidak ada perasaan takut dalam diri siswa baik untuk mengemukakan pendapat atau bertanya, Guru harus lebih sabar dalam membimbing siswa merumuskan kesimpulan/menemukan konsep, Guru harus mendistribusikan waktu secara baik, sehingga kegiatan pembelajaran dapat berjalan sesuai dengan yang diharapkan, Guru sebaiknya menambah lebih banyak contoh soal dan memberi soal-soal latihan pada siswa untuk dikerjakan pada setiap kegiatan belajar mengajar.

\section{Siklus III}

Pada tahap ini, peneliti mempersiapkan perangkat pembelajaran yang terdiri dari rencana pelajaran 3 , soal tes formatif 3 dan alat-alat pengajaran yang mendukung. Selain itu juga, dipersiapkan lembar observasi pengelolaan metode pembelajaran kooperatif model STAD dan lembar observasi aktivitas guru dan siswa.

Pelaksanaan kegiatan belajar mengajar untuk siklus III dilaksanakan pada tanggal 13 September 2017 di kelas VB dengan jumlah siswa 38 siswa. Pelaksanaan metode pembelajaran kooperatif model STAD melalui tahapan berikut ini. Pelaksanaan pembelajaran, Diskusi kelompok, Tes, Penghargaan kelompok, Menentukan nilai individual dan kelompok. Dalam hal ini, peneliti bertindak sebagai pengajar, sedangkan yang bertindak sebagai pengamat yaitu seorang guru PKn dan Wali Kelas VB. Adapun proses belajar mengajar mengacu pada rencana pelajaran dengan memperhatikan revisi pada siklus II, sehingga kesalahan atau kekurangan pada siklus II tidak terulang lagi pada siklus III. Pengamatan (observasi) dilaksanakan bersamaan dengan pelaksanaan belajar mengajar. 


\section{Edutainment : Jurnal Ilmu Pendidikan dan Kependidikan}

Volume 7 Nomor 2 Edisi Juli-Desember 2019

Pada akhir proses belajar mengajar siswa diberi tes formatif III dengan tujuan untuk mengetahui tingkat keberhasilan siswa dalam proses belajar mengajar yang telah dilakukan. Instrumen yang digunakan yaitu tes formatif III dengan tujuan untuk mengetahui tingkat keberhasilan siswa dalam proses belajar mengajar yang telah dilakukan. Instrumen yang digunakan yaitu tes formatif III. Adapun data hasil penelitian pada siklus III dapat dilihat aspek-aspek yang diamati pada kegiatan belajar mengajar (siklus III) yang dilaksanakan oleh guru dengan menerapkan metode pembelajaran kooperatif model STAD mendapatkan penilaian cukup baik dari pengamat, yakni memotivasi siswa, membimbing siswa merumuskan kesimpulan/menemukan konsep, dan pengelolaan waktu.

Berdasarkan observasi tampak bahwa aktivitas guru yang paling dominan pada siklus III yaitu membimbing dan mengamati siswa dalam menemukan konsep, yakni 22,6\%, sedangkan aktivitas menjelaskan materi yang sulit dan memberi umpan balik/evaluasi/tanya jawab menurun masing-masing sebesar (10\%), dan (11,7\%). Aktivitas lain yang mengalami peningkatan yaitu mengkaitkan dengan pelajaran sebelumnya (10\%), menyampiakan materi/strategi/langkahlangkah $(13,3 \%)$, meminta siswa menyajikan dan mendiskusikan hasil kegiatan (10\%), dan membimbing siswa merangkum pelajaran (10\%). Adapun aktivitas yang tidak mengalami perubahan yaitu menyampaikan tujuan $(6,7 \%)$ dan memotivasi siswa $(6,7 \%)$.

Hasil belajar pada siklus III diperoleh nilai rata-rata tes formatif sebesar 7,97 dan dari 38 siswa yang telah tuntas sebanyak 36 siswa dan 2 siswa belum mencapai ketuntasan belajar. Maka secara klasikal ketuntasan belajar yang telah tercapai sebesar 94,74\% (termasuk kategori tuntas). Hasil pada siklus III ini mengalami peningkatan lebih baik dari siklus II. Adanya peningkatan hasil belajar pada siklus III ini dipengaruhi oleh adanya peningkatan kemampuan guru dalam menerapkan metode pembelajaran kooperatif model STAD, sehingga siswa menjadi lebih terbiasa dan lebih mudah dalam memahami materi yang telah diberikan.

Pada tahap ini dikaji apa yang telah terlaksana dengan baik maupun yang masih kurang, baik dalam proses belajar mengajar dengan penerapan metode pembelajaran kooperatif model STAD. Dari data-data yang telah diperoleh dapat diuraikan berikut ini. Selama proses belajar mengajar guru telah mekasanakan semua pembelajaran dengan baik. Meskipun ada beberapa aspek yang belum sempurna, tetapi persentase pelaksanaannya untuk masing-masing 


\section{Edutainment : Jurnal Ilmu Pendidikan dan Kependidikan}

Volume 7 Nomor 2 Edisi Juli-Desember 2019

aspek cukup besar, berdasarkan data hasil pengamatan diketahui bahwa siswa aktif selama proses belajar mengajar berlangsung, kekurangan pada siklussiklus sebelumnya sudah mengalami perbaikan dan peningkatan sehingga menjadi lebih baik, hasil belajar siswa pada siklus III mencapai ketuntasan.

Pada siklus III guru telah menerapkan metode pembelajaran kooperatif model STAD dengan baik, dan dilihat dari aktivitas siswa, serta hasil belajar siswa pelaksanaan proses belajar mengajar sudah berjalan dengan baik. Maka tidak diperlukan revisi terlalu banyak. Tetapi yang perlu diperhatikan untuk tindakan selanjutnya, yakni memaksimalkan dan mempertahankan apa yang telah ada dengan tujuan agar pelaksanaan proses belajar mengajar selanjutnya. Penerapan metode pembelajaran kooperatif model STAD dapat meningkatkan proses belajar mengajar, sehingga tujuan pembelajaran dapat tercapai.

Melalui hasil penelitian ini menunjukkan bahwa metode pembelajaran kooperatif model STAD memiliki dampak positif dalam meningkatkan prestasi belajar siswa. Hal ini dapat dilihat dari semakin mantapnya pemahaman siswa terhadap materi yang disampaikan guru (ketuntasan belajar meningkat dari siklus I, II, dan III) yaitu masing-masing 68,2\%, $81,58 \%$ dan 94,74\%. Pada siklus III ketuntasan belajar siswa secara klasikal telah tercapai. Sedangkan kelompok yang mendapatkan penghargaan yaitu kelompok I dengan nilai kelompok tertinggi sebesar 6,17 .

Berdasakan analisis data, diperoleh aktivitas siswa dalam proses pembelajaran PKn pada pokok bahasan sistem politik dengan metode pembelajaran kooperatif model STAD yang paling dominan yaitu bekerja dengan sesama anggota kelompok, mendengarkan/memperhatikan penjelasan guru dan diskusi antar siswa/antara siswa dengan guru. Jadi dapat dikatakan bahwa aktivitas siswa dikategorikan aktif. Sedangkan untuk aktivitas guru selama pembelajaran telah melaksanakan langkahlangkah kegiatan belajar mengajar dan menerapkan pengajaran kontesktual model pengajaran berbasis masalah dengan baik. Hal ini terlihat dari aktivitas guru yang muncul, diantaranya aktivitas membimbing dan mengamati siswa dalam menemukan konsep, menjelaskan materi yang sulit, memberi umpan balik/evaluasi/tanya jawab, dimana persentase untuk aktivitas di atas cukup besar.

\section{SIMPULAN DAN SARAN}

Berdasarkan hasil penelitian yang telah dipaparkan selama tiga siklus, hasil seluruh pembahasan serta analisis yang telah dilakukan dapat disimpulkan berikut ini. Metode pembelajaran kooperatif 


\section{Edutainment : Jurnal Ilmu Pendidikan dan Kependidikan}

Volume 7 Nomor 2 Edisi Juli-Desember 2019

model STAD dapat meningkatkan kualitas pembelajaran $\mathrm{PKn}$, metode pembelajaran kooperatif model STAD memiliki dampak positif dalam meningkatkan prestsi belajar siswa yang ditandai dengan peningkatan ketuntasan belajar siswa dalam setiap siklus, metode pembelajaran kooperatif model STAD dapat menjadikan siswa merasa dirinya mendapat perhatian dan kesempatan untuk menyampaikan pendapat, gagasan, ide, dan pertanyaan, siswa dapat bekerja secara mandiri maupun kelompok, serta mampu mempertanggungjawabkan tugas individu maupun kelompok, penerapan metode pembelajaran kooperatif model STAD mempunyai pengaruh positif, yakni dapat meningkatkan motivasi belajar siswa.

Agar proses belajar mengajar PKn lebih efektif dan lebih memberikan hasil yang optimal bagi siswa, maka disampaikan saran berikut ini. Untuk melaksanakan metode pembelajaran kooperatif model STAD memerlukan persiapan yang cukup matang, sehingga guru harus mampu menentukan atau memilih topik yang benar-benar bisa diterapkan dengan Metode pembelajaran kooperatif model STAD dalam proses belajar mengajar, sehingga memperoleh hasil yang optimal, dalam rangka meningkatkan prestasi belajar siswa, guru hendaknya lebih sering melatih siswa dengan berbagai metode pengajaran, walau dalam taraf yang sederhana, dimana siswa nantinya dapat menemukan pengetahuan baru, memperoleh konsep dan keterampilan, sehingga siswa berhasil atau mampu memecahkan masalah-masalah yang dihadapi, perlu adanya penelitian yang lebih lanjut, karena hasil penelitian ini hanya dilakukan di Kelas VB semester 1 SD Negeri 3 Pangkalpinang tahun pelajaran 2017/2018, untuk peneltian yang serupa hendaknya dilakukan perbaikanperbaikan agar diperoleh hasil yang lebih baik.

\section{DAFTAR PUSTAKA}

Arikunto, Suharsimi. 2002. Prosedur Penelitian Suatu Pendekatan Praktek. Jakarta: Rineksa Cipta.

Wahyuni, Dwi. 2001. Studi tentang Pembelajaran Kooperatif terhadap Hasil Belajar Matematika. Malang: Program Sarjana Universitas Negeri Malang 